\title{
Un apel pentru predarea scrierii ca proces integrativ cu scop funcțional
}

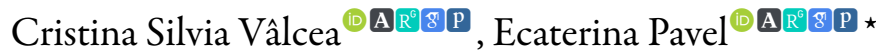 \\ Facultatea de Litere, Universitatea Transilvania din Brașov, Bd. Eroilor 29, 500036 Brașov, România
}

\section{Despre articol}

Istoric:

Primit 18 septembrie 2021

Acceptat 20 octombrie 2021

Publicat 12 decembrie 2021

\section{Cuvinte-cheie:}

scriere

procesul de scriere

produsul scrierii

programa școlară

analfabetism funcțional

\begin{abstract}
Rezumat
În România, situația scrierii ca disciplină școlară este una paradoxală: deși discursul general o declară importantă, se investește tot mai puțin în această abilitate; în plus, suferă o puternică opoziție din partea părinților, care ar opta pentru competențe de scriere digitale, considerate mai de perspectivă pentru copiii lor. Minată atît de școală, cît și de societate, scrierea are slabe șanse de a-şi dovedi rolul determinant în formarea intelectuală a tinerei generații. În această linie, prezenta lucrare urmărește cartografierea scrierii ca abilitate predată la școală, prezentînd mai întîi abordarea românească a scrierii școlare (ca produs sau proces) și, în al doilea rînd, efectuînd o analiză a exercițiilor și cerințelor dedicate scrierii. Scopul este acela de a sublinia plusurile și minusurile acestora și de a sugera schimbări care ar putea îmbunătăți nu numai percepția asupra scrierii în programa școlară românească, ci și calitatea rezultatelor. Pentru a avea o bună înțelegere asupra modului în care scrierea este percepută de sistemul de învăţământ românesc, am considerat că o abordare potrivită este să se analizeze programa școlară emisă și aprobată de Ministerul Educației Naționale și să se evalueze implementarea liniilor directoare oficiale în manualele școlare. Justificarea interesului autorilor pentru scriere este legată de ratele ridicate ale analfabetismului funcțional, de tipul preponderent de evaluare a elevilor (probele scrise) și de incapacitatea în mare măsură recunoscută a elevilor de a-şi gestiona cu succes sarcinile de lucru scrise.
\end{abstract}

\section{Introducere}

Scrierea și mai ales scrisul de mînă par a fi intrinsec asociate cu sistemele de învățămînt învechite, care trebuie să fie suprimate prin intermediul unor noi abordări pedagogice și resurse tehnice. Sistemul de învăţămînt din România s-a confruntat cu probleme fundamentale care au afectat procesul de predare / învățare a scrierii în școala primară și, mai tîrziu, în învățămîntul secundar și superior. Dintr-o perspectivă mai largă, mai cuprinzătoare, principalele provocări sînt reformele educaţionale în continuă schimbare, lipsa resurselor materiale și umane, ratele ridicate de abandon școlar, atractivitatea scăzută a profesiei de profesor și salariile demotivante, lipsa personalului calificat în zonele rurale și îndepărtate, programele slabe de finanțare pentru susținerea echității (Comisia Europeană, Monitorul Educației şi Formării 2019. România, p. 5-9). Analizate din perspectiva mai restrînsă a beneficiarului, provocările variază de la lipsa motivației personale (educaţia nu mai pare un deziderat sau calea spre succes), lipsa plăcerii (elevii petrec multe ore în clasă, învățînd în mare parte noțiuni teoretice pe care nu le folosesc în conexiune cu alte concepte inter- și transdisciplinare), programele dense, insuficient adaptate la nivelurile de vîrstă, și metodele punitive încă utilizate pe scară largă (note mici, punerea la zid a elevilor), care duc la un nivel și mai crescut de demotivare a elevilor.

Predomină încă decalajele dintre mediul rural și cel urban. Pe de o parte, categoriile defavorizate sînt concentrate în mediul rural, unde condițiile dificile şi metodele rudimentare continuă să existe din cauza lipsei fondurilor necesare. Copiii se confruntă cu abandonul școlar timpuriu, navete dificile sau crize

*Adrese de corespondență: cristina.valcea@unitbv.ro (CSV), ecaterina.pavel@unitbv.ro(EP). 
Cristina Silvia Vâlcea, Ecaterina Pavel

diverse cauzate de migrarea părinților la muncă în străinătate (neglijare, abuz, anxietate, depresie, abateri disciplinare, delincvență). Nivelul scăzut de alfabetizare este întotdeauna legat de problemele financiare, psihosociale sau comportamentale specifice zonelor dezavantajate; cu toate acestea, alfabetizarea este singura șansă de a lupta și de a scăpa de sărăcie și de sărăcia extremă. Este un decalaj de cunoștințe care trebuie depăşit pentru a întrerupe cercul vicios al analfabetismului care generează sărăcia și al sărăciei care duce la analfabetismul funcțional.

Pe de altă parte, în zonele urbane școlile par să se îndrepte din ce în ce mai mult către digitalizare, în detrimentul scrisului de mînă. Dar competențele digitale nu înseamnă neapărat alfabetizare funcțională crescută. Un studiu recent estimează că în UE, România se află pe locul al doilea în ceea ce privește analfabetismul funcțional, $44 \%$ dintre tinerii sub 15 ani fiind incapabili să aibă performanțe satisfăcătoare la citire, matematică și științe (OECD, PISA 2018 Results). În școala primară, imediat după atingerea nivelului de alfabetizare de bază, elevii analfabeți funcțional pot citi un text neînțelegînd mesajul acestuia; pot fi capabili să rețină informațiile și să le reproducă bine, fără a avea capacitatea de a le folosi în viaţa reală sau fără a face conexiuni cu alte noțiuni dobîndite; e posibil să aibă dificultăţi de formulare sau să se exprime în scris fără prea multă coerență. Dincolo de motivele menționate mai sus, este de analizat dacă programa școlară contribuie sau nu la forme mai mult sau mai puțin subtile de analfabetism funcțional. Un aspect care va fi explorat mai tîrziu în acest articol.

\section{Scrierea ca proces}

Succesul a fost în mod tradițional legat de bunele abilități de scriere și „un scop de bază al școlii este de a-i învăța pe elevi să devină scriitori competenți”. Dar ce înseamnă „scriitori competenți”” (Graham, 2019, p. 278) în sistemul de învățămînt românesc? Lucrarea noastră își propune să producă o analiză relevantă mai jos.

\subsection{Scris de mînă sau digital?}

În mod previzibil, prima întrebare care se pune este: de ce ar trebui elevii să studieze caligrafia atunci cînd orele, temele, activitățile și chiar examenele tind să fie online? Cînd copiii, de la o vîrstă fragedă, sînt mai implicați în jocurile și activitățile tehnologice decît în cele tradiționale? În ciuda acestor obiecții, scrisul de mînă nu ar trebui respins, susţin cercetătorii. Prin caligrafie asimilăm cognitiv cunoștințe și ne comunicăm. Scrisul de mînă permite acel timp pentru a gîndi, pentru a reflecta asupra structurii, corectitudinii și alegerii cuvintelor. În plus, deși trăim într-o era digitală, organizarea discursului, luarea de notițe, rezumatul, argumentarea se pot realiza mai bine prin scriere de mînă în stadiile incipiente, deoarece asigură stimularea neuronală necesară dezvoltării cerebrale. „Scrisul de mînă este mai mult decît o simplă sarcină ce ține de motricitatea fină; necesită exersarea abilităților perceptiv-motorii, a planificării motrice, a percepției vizuale, a integrării vizual-motorii, a abilităților bilaterale ale mîinii, a folosirii ustensilelor de scris, a kinesteziei, necesită o atenție susținută, o procesare senzorială și prezența componentelor biomecanice adecvate pentru postură și folosirea mîinii” (Lust \& Donica, 2011, p. 560). Mai mult, o mai bună dezvoltare a scrisului de mînă este legată de o mai mare activare neuronală în zonele asociate cu memoria pe termen lung și memoria de lucru (Berninger et al., 2006, p. 84) și , ,ar putea contribui la tratarea dizabilităților de citire, precum și la dezvoltarea normală a citirii” (Berninger et al., 2006, p. 67).

Discuția nu este neapărat despre caligrafie, ci despre actul în sine al scrisului de mînă, care pare să fie înlocuit în curînd de tastare. Pe de o parte, am putea argumenta în favoarea tastării, dacă luăm în considerare că aceasta implică coordonarea ambelor mîini și, prin urmare, produce o conexiune mai bună între emisferele cerebrale. Dar, pe de altă parte, scrierea de mînă apare în principal prin folosirea mîinii drepte, controlată de emisfera stîngă, specializată în procesarea funcțiilor limbajului și producerea vorbirii. Din punctul de vedere al neuroștiinței, creierul funcționează în mod diferit atunci cînd este angajat în tastare, dar încă ne lipsește experiența pentru a spune dacă această schimbare este una pozitivă, negativă sau neutră. Ca adulți care au învățat scrierea de mînă și au folosit-o pe scară largă, trecerea la dactilografiere în 
detrimentul scrisului de mînă nu a avut efecte semnificative asupra activității creierului. Dar tăierea sinaptică și dezvoltarea conexiunilor neuronale la copiii care învață să folosească în mod predominant tastarea pot afecta profund abilitățile cognitive. Scrierea de mînă favorizează memoria vizuală, prin rememorarea unui gest și a formei unei litere făcute prin acel gest. În studiul său, Karin James a arătat cum copiii care au învățat alfabetul prin scriere de mînă recunosc literele mai ușor, ceea ce îi ajută să citească mai repede și mai fluent. Și lectura, la rîndul ei, este importantă pentru succesul școlar: „experiența scrisului de mînă joacă un rol crucial în formarea rețelei cerebrale care stă la baza recunoașterii literelor” și este importantă „pentru înțelegerea literelor și, prin urmare, pentru dezvoltarea alfabetizării. [...] Sistemul motor creează variabilitate (prin scrisul de mînă în acest caz) în lumea noastră perceptivă, fapt care îmbunătățește performanța comportamentală și servește la organizarea sistemelor cerebrale în rețele funcționale" (James, 2017, p. 507).

Instrumentele digitale tind să se învechească mai repede decît stiloul și hîrtia. Așadar, deși poate fi adevărat că scrisul electronic este utilizat pe scară largă astăzi, nu știm cum vor arăta tastaturile de mîine. Ar trebui să ne amintim că, în urmă cu cîțiva ani, tastele telefonului erau folosite diferit decît în prezent și că unele dintre tastaturile de astăzi tind să folosească o mișcare de alunecare pentru a scrie, doar ridicînd degetul între cuvinte. Prin urmare, am putea considera că este de preferat să învățăm elementele de bază ale scrisului într-o manieră tradițională, independent de instrumentele electronice, deoarece acestea pot fi transferate și utilizate în orice împrejurare. În plus, accesul extins la resursele electronice tinde să predispună elevii la lene - nu mai iau notițe, ci fac fotografii: pur și simplu preferă să fotografieze tablă sau flipchartul. Sau își înregistrează profesorul explicînd lecția, iar aceste înregistrări rămîn stocate și nefolosite, dar le dau impresia elevilor că au făcut efortul minim pentru a participa la ore. Mai mult, atunci cînd vine vorba de tastare și de pasivitatea pe care o poate induce, nu putem să nu observăm că funcția AutoCorrect nu ajută prea mult la stăpînirea unei limbi și a regulilor sale gramaticale sau ortografice. Această funcție ne modifică vigilența și capacitatea de a detecta și corecta propriile erori.

\subsection{Aspecte formale ale scrierii}

Înainte de a analiza scrierea ca produs, trebuie să ne concentrăm asupra procesului de scriere. Evident, în școala primară se pune accent pe aspectele structurale, care stau la baza activităților de scris (sau cel puțin ar trebui să stea): caligrafie, ortografie, diacritice, silabe, punctuație etc. Din acest motiv, caligrafia și dictarea erau discipline standard de sine stătătoare în programa claselor I și a II-a, iar decizia recentă de a le elimina pare inexplicabilă. Orele de caligrafie, dictare și citire au fost înlocuite cu un hibrid discutabil, numit „Comunicarea în limba română, care nu mai cuprinde doar caligrafia, citirea sau comunicarea verbală, ci puțin din fiecare și nimic specializat în același timp, ceea ce nu este deosebit de util pentru formarea creierelor tinere. De remarcat este o trăsătură bizară a manualului de clasa a I-a: acesta abundă, încă de la început, în enunțuri și cerințe complexe adresate elevului care nu știe încă să scrie sau să citească. Apoi, din cînd în cînd, la rubrica „Scriem frumos!” apare o propoziție caligrafică, iar elevii sînt îndemnați să producă și ei un scris frumos de mînă. Însă caligrafia necesită ore de practică, aşa că pentru elevii din școala primară caligrafia rămîne o noțiune abstractă, avînd în vedere eliminarea ei din programă. Acest lucru poate duce la frustrare și la scăderea încrederii în sine. Avînd în vedere că accentul se mută, cazînd asupra unor abilităţi disparate, educatorii pot încerca doar să predea competențe de scriere lizibilă și de citire, dar cu un succes îndoielnic.

Predarea ortografiei este un alt element care trebuie reformat sau îmbunătățit. De exemplu, diferența dintre morfemele cu cratimă și cele fără cratime (s-au/sau, i-au/iau etc.) —acestea sînt recapitulate pe scurt în fiecare an, ceea ce ar fi benefic dacă programa nu ar fi atît de densă, iar copiii nu ar uita cea mai mare parte a materiei pe măsură ce avansează în studiile lor. În plus, scrierea cu $\hat{\imath} / \hat{a}$ se predă încă din clasa I. Diferența $\hat{\imath} / \hat{a}$, în sine, este un nonsens lingvistic, dar acest aspect depășește scopul și limitele acestei lucrări. $\mathrm{Cu}$ toate acestea, folosirea a două grafeme pentru același fonem într-o limbă fonetică, în funcție de locul lor (în mijlocul/la începutul sau la sfîrșitul unui cuvînt) tinde să producă confuzie și confuzia crește pe măsură ce elevul află că această regulă se schimbă în cazul cuvintelor compuse sau derivate. Derivarea ar 
putea fi dificil de explicat în școala primară, iar regula în sine este confuză chiar pentru adulți, nu doar în rîndul copiilor cu abilităţi limitate de gîndire abstractă. Un alt exemplu se referă la importanţa scrisului de mînă în raport cu semnele diacritice. Asta pentru că scrierea online tinde să „omită” semnele diacritice: vorbitorii pot pronunța un cuvînt într-un fel și îl pot scrie complet diferit (ceea ce este inadecvat pentru o limbă fonetică). Pe de o parte, acest lucru poate genera confuzii („tară” - defectul ereditar este diferit de "țară” - patrie; „sârmă” - de „sarma” etc.), iar pe de altă parte, am întîlnit elevi sau studenți care nu mai folosesc semnele diacritice nici măcar în scrierea de mînă.

Cu toate acestea, eliminarea orelor de caligrafie și dictare este „compensată” de faptul că mai tîrziu, în cadrul predării unor discipline precum istoria, biologia, geografia etc., profesorii încă apelează în mare măsură la dictare pentru a transmite conținuturi elevilor. Ceea ce, în secolul XXI, se dovedește a fi contraproductiv: în primul rînd, conținutul cursului ar putea fi ușor disponibil pe orice tip de suport, iar accentul ar trebui să se schimbe de la scrierea și teoria învățării pe de rost la înțelegerea și conectarea noțiunilor din diferite discipline. Și, în al doilea rînd, chiar dacă media scrisului de mînă este, teoretic, satisfăcătoare, ea rămîne totuşi o medie între două extreme (practica insuficientă a scrisului de mînă în contexte adecvate versus utilizarea excesivă, ineficientă, care nu stimulează asimilarea corectă, creativitatea, aplicabilitatea). Toate aceste neajunsuri sînt accentuate de procesul de evaluare care necesită redarea fidelă a informațiilor dictate. Nici la disciplinele la care gîndirea critică, imaginația și interpretarea proprie ar trebui să existe (de exemplu, la cursurile de comunicare și literatură), nu este încurajată libertatea de opinie—în învăţămîntul gimnazial și superior, elevii/studenții memorează scheme prin care trebuie să demonstreze că o operă aparține unui anumit gen (liric, epic sau dramatic), ei învață pe de rost caracterizări sau informații despre o operă literară, adesea fără să citească sau să înțeleagă opera în sine, deoarece cadrele didactice care le evaluează lucrările încurajează acest tip de „clonare” a informațiilor. Orice încercare de a ieși din aceste limite rigide poate duce la o notă scăzută, aşa că elevii se aliniază în această armată de scribi și copiști. În plus, utilizarea tehnologiei îi face pe studenți mai susceptibili la plagiat, mai ales atunci cînd le lipsește practica de a distinge între reproducerea literală a informațiilor și redarea liberă a cunoștințelor asimilate. De asemenea, utilizarea necritică a tehnologiei le diminuează capacitatea de a distinge între limbajul protocolar și cel familiar, determinîndu-i să folosească structuri neacademice, colocviale în lucrările formale; ceea ce ne aduce la un aspect mai complex al scrierii:

\section{Scrierea ca produs}

Scrisul este foarte valorizat datorită impactului fundamental pe care îl are asupra dezvoltării și sănătății mintale (Pizarro, 2004, p. 5-12) prin faptul că reduce stresul și crește sociabilitatea, precum și datorită importanței sale în succesul școlar măsurat în teste standard (Espin et al., 2008, p. 174-193). Impactul scrisului asupra psihicului elevilor și realizărilor lor școlare, precum și prioritatea lui la locul de muncă au conferit scrierii o însemnătate la înălțimea căreia școala se ridică cu greu azi. Acest fapt este în mare măsură recunoscut de cercetătorii care identifică fie probleme mecanice, cum ar fi ortografia, punctuația și scrierea de mînă, fie probleme ale sistemului, printre care reticența profesorilor de a preda scrierea (Draper, 2002, p. 357-384) sau problemele lingvistice și cognitive ale studenților care îngreunează scrisul (Kellogg \& Raulerson, 2007, p. 237-242).

Complexitatea scrierii a fost definită ca „o componentă vitală a nivelului de alfabetizare a elevilor și [...] un instrument critic de comunicare pentru ca elevii să transmită gînduri și opinii, să descrie idei și evenimente și să analizeze informații. Într-adevăr, scrisul este o abilitate durabilă care joacă un rol cheie în succesul studiilor academice și profesionale" (Institute of Education Sciences, 2016, p. 1). S-a susținut, însă, că tocmai această complexitate a scrisului poate reprezenta o piedică în calea atingerii unui nivel mai înalt de practică a scrierii. Alte definiții ale complexității scrierii se concentrează pe ideea de scop, ceea ce evidențiază intenția și motivația care ar trebui să stea la baza tuturor sarcinilor de scriere: „,[scrisul este] codificarea și transpunerea semnificației într-un text scris pentru a atinge anumite scopuri” (Harris \& Chapman, 2004, p. 417-431). 
Complexitatea este reprezentată şi de abilitățile metalingvistice (organizarea retorică) și metacognitive (utilizarea adecvată a limbajului, limbajul specific, cunoștințele lexicale și sintactice) care demonstrează conștientizarea dobîndită de elev în procesul de scriere. Deoarece învăţarea scrierii este treptată, toate aceste perspective asupra scrisului arată etapele reale ale învățării sale, de la școala primară pînă la scrierea profesională și academică. Un argument valoros pentru necesitatea predării scrierii datorită complexităţii sale este cel oferit de Kellogg $(2008$, p. 2) care susține că scrisul este în mod greșit înțeles ca trăsătură inerentă a oamenilor, aşa cum este vorbirea: „Capacitatea învăţată de a compune un text amplu valid ar trebui înțeleasă ca o sarcină similară cu dobîndirea de competențe în domenii conexe, dobîndite cultural. $\mathrm{Nu}$ este doar o extensie a aparentei noastre predispoziții biologice de a dobîndi limbajul vorbit."

Dat fiind faptul că abilitățile de scriere se dezvoltă treptat, și sistemul educațional românesc are o abordare graduală privind introducerea elementelor scrierii. Toate concluziile se bazează pe programa națională emisă și aprobată de Ministerul Educației.

\begin{tabular}{l|l} 
6-7 ani & $\begin{array}{l}\text { scrierea începe cu recunoașterea şi numirea literelor şi cu dezvoltarea } \\
\text { mușchilor implicați în scrisul de mînă. }\end{array}$ \\
\hline $7-8$ ani & $\begin{array}{l}\text { literele de mînă, primele texte scrise copiate: bilete, invitații, cărți poștale, } \\
\text { cu accent pe aspect, dictarea literelor și silabelor, postere. }\end{array}$ \\
\hline $8-9$ ani & $\begin{array}{l}\text { copierea și transcrierea literelor, silabelor, cuvintelor, propozițiilor, cu } \\
\text { accent pe aspect, postere. }\end{array}$
\end{tabular}

\section{Dezvoltarea abilităţilor de scriere în sistemul școlar primar românesc}

Scrierea ca produs constă în principal în imitarea unui model care este studiat în ceea ce privește elementele componente, aspectele tehnice și aşezarea în pagină cu scopul de a reproduce atît conținutul, cît și structura. Inovația sau creativitatea sînt limitate, întrucît scopul principal al acestui tip de scriere este acela de a-i obişnui pe elevi să redacteze documente după model: email-uri, rapoarte, invitaţii, cărți poștale, scrisori etc., ceea ce este de preferat în acest caz. Cu alte cuvinte, este vorba despre învățarea formelor care vor permite exprimarea (Davies, 1988, p. 130-142), care este preponderent imitativă și nu reușește să implice elevii în producerea textului, avînd în vedere natura prescriptivă a documentelor. Badger \& White (2000, p. 153-160) susțin că în abordarea scrierii ca produs, limba este cea care are de cîștigat deoarece ceea ce este evaluat este acuratețea gramaticală a producției. Scrierea este pe locul doi sau reprezintă scuza pentru atribuirea sarcinii de lucru. Mai mult, scrierea în general primește o atenție redusă deoarece este considerată mai puțin importantă decît comunicarea orală. Cîștigul elevilor constă în cunoștințele pe care le dobîndesc despre cum să producă un astfel de text model. Accentul este pus pe produsul final și pe analiza modelului care trebuie imitat.

Scrierea ca proces a apărut ca reacție la scrierea ca produs în încercarea de a oferi elevilor mai multă libertate atunci cînd își exprimă ideile. Etapele premergătoare scrierii propriu-zise se bucură de o mare importanță, deoarece brainstorming-ul și planificarea își dovedesc eficiența în realizarea scrierii. Etapele care au loc după scriere sînt la fel de importante, deoarece revizuirea, corectarea și îmbunătățirea fac parte din procesul de scriere. Intervențiile externe de diferite naturi, fie oferite de profesor, fie de colegi, sînt considerate a fi benefice pentru elevi, deoarece adaugă mai multă reflexivitate textului. Feedback-ul este, prin urmare, esențial pentru abordarea scrierii ca proces deoarece oferă indicii despre modul în care textul s-ar putea dezvolta în beneficiul elevului. Cu toate acestea, dacă există ceva la care a contribuit abordarea scrierii ca process, aceasta este cu siguranță dezvoltarea unui simț al cititorului, care transformă scrierea dintr-un demers inutil într-un produs care ar putea atrage un anumit public, ceea ce influențează scrierea sub aspectul credibilității, al explicațiilor reale la care ar putea primi un răspuns. Boughey $(1997$, p. 127) subliniază că „necesitatea de a acorda atenție publicului textului îi determină pe scriitori să anticipeze și să ia în considerare alte puncte de vedere decît ale lor. Rezultatul este că propozițiile din conținutul textului sînt susceptibile de a fi analizate mai riguros decît dacă ar fi pur și simplu gîndite”. 
Cristina Silvia Vâlcea, Ecaterina Pavel

Performanța școlară slabă în ceea ce privește scrierea a elevilor români este de departe un caz aparte. Cercetările susțin o generalizare a problemelor de scriere ca simptom al unui sistem educațional căruia îi lipsește timpul pentru a investi în scrierea elevilor. De fapt, scrierea presupune o mare investiţie de timp și efort (Berman \& Cheng, 2010, p. 25-40) pentru a deveni o abilitate eficientă, capabilă să le ofere elevilor avantajul de a fi pe deplin pregătiți să scrie. Totuși, sistemul educațional românesc abordează scrierea ca pe un produs care este realizat pe loc ca orice exercițiu de gramatică sau de vocabular. Ca o ilustrare a cerințelor de scriere care sînt predominante în sistemul de învățămînt românesc, le analizăm pe cele din manualele românești pentru clasele I și a II-a care sînt aprobate de Ministerul Educației din România. Făcînd lucrul acesta, intenția noastră este să analizăm modul/modurile în care manualele românești predau scrierea elevilor foarte mici și cum sînt puse bazele scrierii. Elementele care prezintă interes pentru cercetarea noastră sînt: formularea cerinței de scriere cu accent pe claritate și complexitate, pregătirea cerinței de scriere sau etapele premergătoare (cerințe de scriere, vocabular și structuri gramaticale de utilizat), brainstorming și selectarea celor mai bune idei care să fie incluse în text. Deși procesul de scriere continuă, de obicei, dincolo de etapele menționate anterior cu redactarea succesivă de variante, evaluarea și feedback-ul profesorului și rescrierea pe baza instrucțiunilor profesorului, cercetarea noastră se limitează la cerințele de scriere din manuale, deoarece interesul nostru este acela de a identifica politicile de scriere acceptate de stat pentru elevii din clasele primare. Evaluarea și feedback-ul profesorilor pot fi cu greu catalogate drept unitare și în mare măsură generate ca o politică de stat, deși aceste aspecte ar trebui să sufere o transformare în direcția standardizării și a creșterii importanței.

\section{Rezultate și discuții}

După selectarea cerințelor de scriere din două manuale pentru clasa I și a II-a, acestea au fost organizate pe categorii, deoarece a devenit clar că ele urmează niște tipare repetitive de-a lungul cărții. Astfel, majoritatea cerințelor de scriere le solicită elevilor să identifice anumite tipuri de cuvinte în textele pe care le studiază (cuvinte care conțin o anumită literă sau care încep cu o anumită literă) pe care ulterior trebuie să le introducă în propoziții proprii. Un alt tip de cerință le cere elevilor să alcătuiască propoziții pentru a include anumite cuvinte în ele. Uneori, elevilor li se cere să scrie fragmente de text mai libere unde trebuie să scrie pe o anumită temă, fără a li se impune să folosească anumite cuvinte sau expresii (scrieți despre rolul cărților în viața oamenilor, descrieți-vă bunica/bunicului). O cerință destul de frecventă le solicită elevilor să transcrie, adică, să copieze anumite cuvinte din text sau părți ale acestuia. La o primă analiză, se poate concluziona că cerințele de scriere sînt de trei tipuri: neproductive (ex. transcrie), semi-productive (ex. scrie propoziții care ar trebui să conțină...) și productive (ex. scrie o descriere a ..., scrie despre rolul lui ...). Instrucțiunile pentru toate cerințele de scriere sînt scurte, indicînd exact rezultatul pe care se așteaptă să îl producă elevii. În unele cerințe, accentul se pune pe scriere ca o abilitate tehnică de a scrie cuvinte sau propoziții, în timp ce în altele scrierea este tratată ca o abilitate care implică scrierea pe un subiect, respectînd vocabularul, regulile gramaticale și modelele organizatorice.

Tipuri de cerinţe:

- Scrieți o propoziție care să conțină următoarele cuvinte.

- Scrieți, selectînd din text un cuvînt care să conțină fiecare dintre următoarele litere în poziția inițială.

- Scrieți un enunț despre prima zi de școală din viața ta.

- Alcătuiți propriile propoziții în care fiecare cuvînt să înceapă cu aceeași literă.

- Scrieți un enunț despre rolul cărților în viața oamenilor.

- Însoțiţi desenul cu cîteva enunțuri sugestive.

- Transcrieți cuvintele subliniate în text..

- Scrieți o descriere a bunicii/bunicului tău.

O primă observație care merită adusă în discuție este tipul de scriere pe care școala românească îl predă prin cărțile pe care le produce și le folosește. Deși se poate susține că tipul de scriere nu poate fi dedus în 
mod natural pe baza cerințelor, este destul de ușor de demonstrat că modul în care este formulată cerința are un impact mare asupra succesului sau eșecului activității de scriere. Astfel, pentru a participa activ la activitate, elevii trebuie să se simtă motivați să lucreze la ea, motivație care poate fi dată de cerința care este clară, bine susținută de argumente, iar elevii înțeleg motivul pentru care lucrează la ea și înțeleg și rezultatul eforturilor lor (Ellis, 2003, p. 57-63). Mai mult, Lee (1999, p. 77) consideră că cu cît cerinţa este mai organizată și mai clară, cu atît rezultatele pe care le vor obține elevii vor fi mai bune. Formularea scurtă a cerințelor nu este neapărat în avantajul elevului, avînd în vedere vîrsta lor. Dimpotrivă, cerința ar trebui să fie atît de lungă cît este nevoie pentru a clarifica pașii pe de o parte și pentru a motiva elevii pe de altă parte. Dörnyei (2001, p. 120) pledează în favoarea explicației „scopului și utilităţiii” cerinței. Din acest punct de vedere, manualele de limba română care au fost analizate în ceea ce privește cerințele de scriere nu au reușit să prezinte elevilor scopul și utilitatea. Și nu din cauză că nu există nici un scop sau utilitate, ci pentru că, neprezentîndu-le clar publicului țintă, acesta poate să le înțeleagă greșit sau să le considere inutile. Cu toate acestea, sîntem pe deplin conștienți de faptul că rolul profesorului este de a adapta materialul din manual și de a ajuta elevii să înțeleagă o sarcină în termeni de scop și utilitate, dar este de la sine înțeles că autorii de manuale și autoritățile au rolul de a produce materiale care încurajează educația și vizează îmbunătățirea abilităților de scriere ale elevilor.

În plus, atunci cînd sînt introduse noi tipuri de cerințe, este recomandat să fie oferite exemple sau modele, astfel încît elevii să înțeleagă ce se așteaptă de la ei sau ce ar trebui să facă. Un avantaj suplimentar al furnizării unui model este dificultatea pe care Skehan (1996) o definește ca „cerința cognitivă” pe care elevii o experimentează atunci cînd sînt expuși la o cerință nouă. Manualele care au fost analizate nu au oferit niciun model sau exemplu pentru cerințele obișnuite de scriere. Cu toate acestea, sînt oferite modele cînd vine vorba de modelul care ar trebui să fie respectat atunci cînd copiaţi un text sau o poezie în caiet. Poziția exactă a datei, titlul și autorul sînt strict indicate cu ajutorul unui model scris de mînă introdus în manual. Este adevărat că utilizarea corectă a datei, titlului și autorului poate contribui la aspectul estetic al scrierii, dar cu greu poate îmbunătăți abilitățile reale de scriere ale elevilor. Pentru a exemplifica, manualul îi instruiește pe elevi despre ceea ce se așteaptă să facă și îi sfătuiește să „scrie textul, respectînd regulile de ortografie și de punctuație și așezarea în pagină”. Aceasta este încă o dovadă a faptului că scrierea pentru autorii acestor manuale este o tehnică care se bazează pe elemente externe și nu pe elemente interne și intrinseci scrierii.

Organizarea cerințelor în trei etape este benefică atît pentru elevi, cît și pentru profesori. Elevii beneficiază de organizarea în trei părți prin faptul că iau contact cu o cerință numită „cerință preliminară” care este menită să-i ajute să înțeleagă, să exerseze, să structureze și să schițeze pentru etapa următoare. Cerința preliminară este o oportunitate de a încorpora informații noi în cunoștințele pre-existente, ceea ce își dovedește utilitatea în imaginea de ansamblu a predării și învățării scrierii. Cerința propriu-zisă este timpul în care elevii produc de fapt conținut în conformitate cu ceea ce s-a predat în timpul cerinței preliminare. Ultima etapă, numită 'cerința ulterioară', este privită ca o continuare care îmbunătățește înțelegerea, experiența și îi expune pe elevi la exersare ulterioară. Întrucît scrierea este complexă și este considerată dificilă atît de elevi, cît și de profesori, este cu atît mai necesar să se pregătească cerințele de scriere pînă la cele mai mici detalii care ar putea ajuta elevii să-și îmbunătățească scrierea. Pentru majoritatea cerințelor de scriere din manualele analizate nu există o „cerință prealabilă”, ceea ce înseamnă că elevii scriu direct, fără nicio introducere anterioară în subiect. Manualele examinate se remarcă prin pregătirea redusă sau inexistentă a scrierii. Fără vocabular adecvat subiectului cerinței de scriere, fără reguli gramaticale care ar putea fi frecvente în acel tip de scriere, fără crearea anterioară de idei care ar putea fi incluse, fără responsabilitatea insuflată copiilor în ceea ce privește decizia asupra ceea ce urmează să introducă și să elimine, fără a preda scrierea ca pe o activitate care se adresează unor cititori reali, scrierea a fost transformată într-o povară cu care elevii români se luptă ineficient. Absența pregătirii elevilor pentru ideea de public cititor este semnificativă pentru puțina importanță pe care scrierea, ca produs real al eforturilor elevilor, o are. Incapacitatea sistemului educațional de a crea un cadru educațional care să simuleze situații din viața reală are ca rezultat performanțele slabe ale elevilor la scris. 
Atunci cînd scrierea este ghidată, deși acele cazuri sînt destul de rare, indicațiile din manual sînt simple impuneri care îți spun ce să faci, nu cum să faci. Elevilor de clasa a II-a li se cere să scrie o compunere liberă pe baza unor imagini și sînt sfătuiți să scrie mai întîi propoziții despre fiecare imagine, apoi li se sugerează să îmbogățească propozițiile adăugînd „expresii frumoase”. În primul rînd, este de remarcat faptul că cerința sugerează că ar trebui să existe etape succesive în scrierea compunerii libere prin cerința ca propozițiile să fie îmbogățite, deși acest lucru nu este solicitat în mod deschis. Destul de interesant, „expresiile frumoase” nu sînt date, iar elevii trebuie să le cunoască și să le introducă, fiecare dintre ele depinzînd de propriile cunoștințe despre „expresiile frumoase”. Încercarea de ghidare este prescriptivă și lipsită de valoarea educațională reală care i-ar putea ajuta pe elevi să descopere scrierea. O altă cerință de scriere care este frecvent utilizată în manualele românești este jurnalul care se presupune că încurajează practicarea unui tip de scriere liberă de către elevi. Cu toate acestea, avînd în vedere faptul că scrierea nu este spontană, chiar și scrierea liberă ar trebui predată și învățată. Mai mult, jurnalul este o specie literară care, deși personală, are un caracter de mărturisire care, pentru acuratețe și conformitate, ar trebui scris într-un anume stil.

Un alt aspect derutant al manualelor analizate este limbajul textelor studiate și, uneori, al cerințelor în sine: de multe ori, copiii sînt nevoiți să studieze texte cu limbaj arhaic sau învechit, foarte nefiresc și diferit de vocabularul folosit de copiii de 7-8 ani (de exemplu, poezii din secolul al XIX-lea care prezintă dificultăți nu numai la nivel lexical, ci și sintactic). În plus, conținutul unor cerințe este problematic. De exemplu, elevilor de clasa a II-a li se cere „să scrie două motive care justifică” un proverb învechit: „cartea este o comoară de învățătură". În primul rînd, formularea învechită a proverbului generează provocări de înțelegere cauzate de vîrstă. În al doilea rînd, copiii trebuie să fie de acord automat (trebuie să justifice afirmația, astfel încît ei nu au voie să aibă o altă părere), ceea ce ridică întrebări cu privire la relația dintre scriere și gîndirea critică. Și în al treilea rînd, nu li se oferă o structură și exemple de texte sau propoziții argumentative.

Revenind la problema scrierii de succes, Graham (2019) afirmă că un program de scriere solid este condiționat în primul rînd de efortul profesorilor care dedică „un timp considerabil predării scrierii” — un lux pe care profesorii români nu și-l pot permite, din cauza timpului necesar pentru sarcini administrative și birocratice suplimentare pe care trebuie să le facă. Cînd a analizat strategiile de succes, Graham a observat o constantă fundamentală: „profesorii au făcut în mod obişnuit o mulțime de adaptări pentru copiii cu probleme de scriere din clasa lor". O strategie cheie greu de folosit în România, din cauza a doi factori: în primul rînd, este greu să gestionezi clase de 30 de elevi și să dai atenție fiecăruia dintre ei, cu accent pe cei care învață mai încet. Și în al doilea rînd, este greu (deși imperativ) să rupi tradiția de a-i „pedepsi” pur și simplu pe elevii care au probleme.

\section{Concluzii}

În marea lor majoritate, declarațiile publice și reformele adoptate în învățămîntul școlar românesc au subliniat rolul important al competențelor scrise în procesul de învățare. Cu toate acestea, scrierea văzută atît ca proces, cît și ca produs, s-a confruntat cu rezistență și a suferit, de asemenea, diverse transformări cu rezultate îndoielnice. Astfel de transformări și rezultate au fost analizate în articolul de faţă, cu accent pe scriere în școala primară, clasa I și a II-a.

Se poate susține că scrierea poate fi predată cu greu în prima parte a școlii primare și că copiii nu pot înțelege termeni complecși și complicati despre scriere, ceea ce este complet adevărat. Cu toate acestea, scrierea în școala primară nu este despre concepte sau despre performanță. Este vorba despre o pledoarie pentru importanța scrierii de care elevii trebuie să fie conștienți, este vorba despre învățarea puterii cuvintelor atunci cînd le combină, este vorba despre o încurajare continuă a elevilor să-și exprime gîndurile, este vorba despre eforturile permanente ale profesorilor de a populariza scrierea în rîndul elevilor ca mijloc de comunicare adecvată, la fel de importantă precum comunicarea orală. Este, sau ar trebui să fie. Și este, la cel mai profund nivel, o chestiune de reformare fundamentală a sistemului de învățămînt românesc 
începînd cu pregătirea cadrelor didactice, cu manualele școlare și cu utilizarea eficientă a resurselor umane și financiare. Prin urmare, factorii de decizie ar trebui să pună educația pe primul plan al agendei lor și să-și pună la îndoială teoriile despre ceea ce face o școală bună. O școală care nu mărește inegalitatea și nu produce analfabetism funcțional. O școală concepută pentru a educa fiecare copil.

\section{Bibliografie}

\section{A. Surse}

Comisia Europeană (2019). Monitorul Educației și Formării 2019. România, [online].

Institute of Education Sciences (2016). Teaching Secondary Students to Write Effectively, [online].

OECD (2019). PISA 2018 Results. Volume I: What Students Know and Can Do, OECD Publishing, Paris, [online].

\section{B. Referințe}

Badger, R. \& White, G. (2000). A process genre approach to teaching writing, în „ELT Journal”, 54 (2), p. 153-160, Crossref.

Berman, R. \& Cheng, L. (2010). English academic language skills: perceived difficulties by undergraduate and graduate students, and their academic achievement, în „Canadian Journal of Applied Linguistics”, 4 (1-2), p. 25-40, [online].

Berninger, V., Abbott, R., Jones, J., Wolf, B., Gould, L., Anderson-Youngstrom, M., Shimada, S. \& Apel, K. (2006). Early Development of Language by Hand: Composing, Reading, Listening, and Speaking Connections; Three Letter-Writing Modes; and Fast Mapping in Spelling, în "'Developmental Neuropsychology”, 29 (1), p. 61-92, Crossref.

Boughey, C. (1997). Learning to write by writing to learn: A group-work approach, în „ELT Journal”, 51 (2), p. 126-134, Crossref.

Bromley, H. (2006). Making my own mark - Play and writing, Early Education, London.

Davies, F. (1988). Designing a writing syllabus in English for Academic Purposes: process and product, în Robinson, P. (ed.), Academic Writing: Process and Product, Modern English Publications, London / Hong Kong, p. 130-142.

Dörnyei, Z. (2001). Motivational Strategies in the Language Classroom, Cambridge University Press, Cambridge, Crossref.

Draper, R. (2002). Every Teacher a Literacy Teacher? An Analysis of the Literacy-related Messages in Secondary Methods Textbooks, în „Journal of Literacy Research", 34 (3), p. 357-384, Crossref.

Ellis, R. (2003). Task-based Language Learning and Teaching, Oxford University Press, London.

Espin, C., Wallace, T., Campbell, H., Lembke, E., Long, J. \& Ticha, R. (2008). Curriculum-Based Measurement in Writing: Predicting the Success of High-School Students on State Standards Tests, în „Exceptional children”, 74 (2), p. 174-193, Crossref.

Graham, S. (2019). Changing How Writing Is Taught, în „Review of Research in Education”, 43 (1), p. 277-303, Crossref.

Harris, A. \& Chapman, C. (2004). Improving schools in Difficult Contexts: Towards a Differentiated Approach, în „British Journal of Educational Studies", 52 (4), p. 417-431, Crossref.

James, K. (2017). The Importance of Handwriting Experience on the Development of the Literate Brain, în „Current Directions in Psychological Science", 26 (6), p. 502-508, Crossref.

Kellogg, R. (2008). Training writing skills: A cognitive development perspective, în „Journal of Writing Research”, 1 (1), p. 1-26, Crossref.

Kellogg, R. \& Raulerson, B. (2007). Improving the writing skills of college students, în „Psychonomic Bulletin \& Review”, 14, p. 237-242, Crossref.

Lee, J. (1999). Tasks and Communicating in Language Classrooms, McGraw-Hill Humanities, New York.

Lust, C. \& Donica, D.(2011). Effectiveness of a Handwriting Readiness Program in Head Start: A Two-group Controlled Trial, in „American Journal of Occupational Therapy”, 65 (5), p. 560-568, Crossref.

Mihăilescu, C. \& Pițilă, T. (2018). Comunicare în limba română: manual pentru clasa a II-a, Editura didactică și pedagogică, București.

Pizarro, J. (2004). The Efficacy of Art and Writing Therapy: Increasing Positive Mental Health Outcomes and Participant Retention After Exposure to Traumatic Experience, în „Art Therapy”, 21 (1), p. 5-12, Crossref.

Skehan, P. (1996). A framework for the implementation of task-based instruction, în „Applied Linguistics”, 17 (1), p. 38-62, Crossref. 